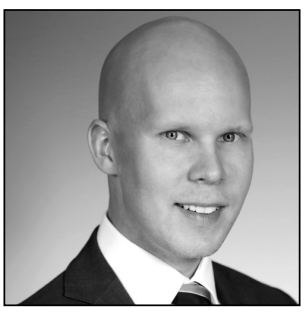

Antti Makkonen

Licentiate of Laws

Doctoral Candidate, University of Lapland

\title{
Instant Loans: Problems and Regulations in Finland
}

\section{Introduction}

\subsection{The market situation and problems in Finland}

Instant loans have been a hot topic among citizens, authorities, businesses, media, politicians, researchers, and the legislature in recent years in Finland-i.e., since the first instant loans were granted via SMS, in $2005 .{ }^{*}{ }^{1}$ The instant loan was an unprecedented financing product; it opened the credit market to people previously excluded from it, and the general interest in the instant-loan business led to new companies. Accordingly, the expansion of the instant-loan business was very rapid.

Instant loans have faced general disapproval: they have been seen as a financial abuse of weak consumers, often using aggressive and tempting marketing. According to several research reports and statistics, it is unquestionable that instant loans have caused severe over-indebtedness problems for many consumers. On the other hand, instant loans can be described as a solution for consumers suffering from short-time shortage of money without invoking of credit cards or other consumer credit of larger amounts. ${ }^{{ }_{2}}$

There is no official or legal definition for an instant loan. Usually it is understood as lump-sum consumer credit amounting to a few hundred euros that should be paid back in two weeks to three months. Since the loan amount is low and the repayment period is very short, the actual annual percentage rate of credit costs is very high. ${ }^{*}$ In Finland, instant-loan operations are conducted by businesses other than banks and credit institutions.

In general, consumer loans are very common in Finland-along with other Western countries. Plentiful consumer loan-taking has become an everyday phenomenon and is socially accepted. ${ }^{*}$ One development of the last decade can be described as a shift from a savings society toward a credit society. ${ }^{*}{ }^{*}$ This is a very

1 There is no precise information about when the instant-loan market was established, but several sources indicate that it occurred in 2005. For instance, see V. Pönkä, E.-L. Parkkali. Pikaluottojen oikeudelliset ongelmat ['The legal problems of instant loans']. - Defensor Legis 2010/5, p. 585 (in Finnish); Finnish Ministry of Justice. Report of the Instant Loan Working Group 'Pikaluottolainsäädännön muuttaminen' ['The amendment of consumer-credit provisions pertaining to instant loans'], report 17/2012, OM 17/41/2011 (in Finnish).

2 According to the opinion of Suomen Pienlainayhdistys ry (the Finnish Instant Loan Association), included in the report of the Instant Loan Working Group (see Note 1).

3 The average APR was approximately 900\% in 2011. See the report of the Instant Loan Working Group, p. 29 (see Note 1).

4 V. Muttilainen. Luottoyhteiskunta. Kotitalouksien velkaongelmat ja niiden hallinnan muodonmuutos luottojen säännöstelystä velkojen järjestelyyn 1980-ja 199o-luvun Suomessa ['The Credit Society: The Indebtedness Problems of Households and Change from Credit Rationing to Debt Arrangements in 1980 s and 1990s Finland']. Helsinki 2002 (in Finnish); K. Rantala, H. Tarkkala. Luotosta luottoon. Velkaongelmien dynamiikka ja uudet riskiryhmät yhteiskunnan markkinalogiikan peilinä ['From trust to credit: The dynamics of indebtedness problems and new risk groups']. - Yhteiskuntapolitiikka 2010/1, p. 20 (in Finnish).

5 V. Muttilainen (see Note 4). 
pertinent description in view of the fact that over 50\% of Finns had some form of loan in 2013 and about a third of Finns had consumer credit, and that these proportions have been quite stable for about a decade. ${ }^{* 6}$ However, the average amount of consumer credit has been decreasing over the last five years-in spring 2013, the average amount of consumer credit per debtor was EUR 8,100, but in 2009 the amount was EUR 9,800."7 The most popular types of consumer credit are bank loans ( $16 \%$ of all consumer debtors), bank accounts with a credit limit (17\%), credit cards (5\%), and hire purchase (5\%). ${ }^{* 8}$ Instant loans are clearly more uncommon. Only 2.4\% of all consumers who have some form of consumer credit had instant loans in spring 2013. ${ }^{*} 9$

At first it seems that instant loans do not play a remarkable role in consumers' total indebtedness. However, instant loans are a cause of one third of all court decisions related to consumer debt claims (see the chart in Section 9), heavily burdening the district courts and also enforcement authorities. In fact, this proportion has been increasing in the last five years.

Easily accessible instant loans have proved to be quite a popular financing product, especially for those lacking the opportunity to obtain a loan from a bank or other, similar credit company by reason of their weak financial standing. According to several research reports, instant loans have been the most common among consumers who engage in only short-term planning of their financial situation or who have problems with controlling their financial issues, along with those whose income is low or whose expenditures have exceeded their income, especially single parents, the young, and the unemployed. ${ }^{* 10}$ Furthermore, about $60 \%$ of instant-loan debtors have taken out more than one instant loan. ${ }^{* 11}$ Several Web forum discussions pertaining to instant-loan problems were analysed in 2012. ${ }^{*}$ This research indicates that in some cases the shame of indebtedness and the fear of getting a bad credit history may even cause panic-driven obtaining of instant loans aimed at repayment of the previous loans. This reactive instant-loan behaviour results in skyrocketing indebtedness stemming from the high costs of the loans, but at the same time the over-indebted consumer may still retain a good credit history if paying back the loans on time. Instant loans are not the only reason for consumers' over-indebtedness problems, but they still play a considerable role: a survey of financial and debt advisers (conducted in 2011) indicates that about half of the advisers consider instant loans to be the main reason for the over-indebtedness problems of the majority of their clients. ${ }^{{ }^{1} 13}$

\subsection{Overview of the consumer-credit regulations}

The Consumer Protection Act ${ }^{* 14}$ (CPA) is the general law applicable in business-to-consumer relations. The most important consumer-credit regulations can be found in its Chapter 7. In December 2010, the whole chapter was revised in connection with the implementation of the Consumer Credit Directive, but the chapter includes also non-harmonised, purely national provisions. The CPA's Chapter 7 includes regulation of consumer-credit contracts, consumer-credit marketing, and contractual relations to be followed

6 Federation of Finnish Financial Services. Säästäminen, luotonkäyttö ja maksutavat ['Savings, credits, and payments'], spring 2013 (in Finnish). Available via http://www.fkl.fi/ (most recently accessed on 12.4.2014).

7 Ibid.

8 Ibid.

9 Ibid.

10 Ibid.; R. Kaartinen, J. Lähdemaa. Miten ja mihin nuoret käyttävät pikavippejä ja muita kulutusluottoja? ['For What Purposes and How Do Young People Use Instant Loans and Consumer Credit?']. Ministry of Trade and Industry (MTI-financed studies) 10/2006, November 2006; E. Valkama, V. Muttilainen. Maksuvaikeudet pikaluottomarkkinoilla ['Payment Difficulties Associated with SMS Loans']. Helsinki: National Research Institute of Legal Policy (Research Communications No. 86) 2008, pp. 46-49 (in Finnish). See also A. Peltonen, Department of Consumer Law. Kuluttajavelallisen aseman parantamiseen tähdänneet toimenpiteet 1990-luvulta lähtien ['Measures Aimed at Improving the Position of the Consumer Debtor Since the 1990s in Finland']. Finnish Consumer Agency (Publications Series 1/2009), pp. 21-23 (in Finnish); O. Juurikkala. Essays on Psychology and Morality in Economic Analysis of Law: Behavioral Paternalism in Consumer Credit Regulation. Joensuu, Finland: Publications of the University of Eastern Finland (Dissertations in Social Sciences and Business Studies, No. 40) 2012, pp. 12-13.

11 Federation of Finnish Financial Services (see Note 6).

12 K. Rantala. Vippikierteen muotokuva ['The "portrait” of instant-loan thread']. National Research Institute of Legal Policy, Research Brief 24/2012 (in Finnish). Available via http://www.optula.om.fi/ (most recently accessed on 12.4.2014).

13 Finnish Consumer Agency. Kysely talous- ja velkaneuvojille velkaantumisen taustatekijöistä 2011 ['Survey for Financial and Debt Advisers about the Background to Consumers' Indebtedness']. Available via http://www.kuluttajavirasto.fi/ (most recently accessed on 12.4.2014) (in Finnish).

14 Kuluttajansuojalaki (Consumer Protection Act), 20.1.1978/38, as amended. 
throughout the credit 'life cycle'. In addition, Chapter 6a of the CPA sets forth some disclosure obligations for distance selling of various financial products, such as consumer credit.

Alongside the CPA's Chapter 7, chapters 2 and 3 lay out general provisions on marketing to all kinds of consumers and on consumer relations, including those in which consumer credit is involved. In this respect, the legislation is based on the directive on unfair business-to-consumer commercial practices in the internal market (Directive 2005/29/EC). In practice, the role of these regulations is quite limited, as the CPA's Chapter 7 contains very specific and detailed provisions addressing consumer-credit relationships and credit-marketing.

The Credit Information Act ${ }^{* 15}$ (CIA) includes the provisions for personal and business credit data. According to the CIA, 'credit data' is defined as data pertaining to the payment ability or willingness to pay of a natural person or a company and that are used in granting or controlling of credit. Consequently, the provisions of the CIA are applied for almost all of the information handled during the lending process. The CIA also provides regulation on credit-data registries, such as requirements applying to credit-data businesses, the content of a credit-information register, and time limits associated with credit-data register entries.

The Interest Act ${ }^{*} 6$ (IA) regulates the interest rate for late payment. In addition, an amendment to the Consumer Protection Act, which entered into force on 1.6.2013, imposes a limit on the interest rate for the cost of consumer credit of less than EUR 2,000. ${ }^{* 17}$

The Act on Registration of Creditors ${ }^{*} 18$ (also referred to as the Registration Act, or RA), which was enacted in connection with the comprehensive reform of the CPA's Chapter 7, requires that consumer creditors principally hold a certain registration if they are to be allowed to conduct consumer lending business. The purpose of the act was to enhance the supervision of consumer lending and to ensure the professionalism and reliability of the creditors.

In addition to consumer-protection legislation, there are several laws that apply in cases of consumer indebtedness and payment problems. The Debt Collection Act ${ }^{* 19}$ (DCA) regulates the debt collection related to consumer credit and other receivables from consumers, setting forth, inter alia, good debt-collection practice, limitations to debt-collection costs, and disclosure obligations. Consumers' financial and debt counselling is a governmental service with its own special law (the Act on Financial and Debt Counsel$\left.\operatorname{ling}^{{ }^{2} 2}\right)$. The over-indebted consumer has an opportunity to apply for the adjustment of private debts under the Act on the Adjustment of the Debts of a Private Individual ${ }^{* 21}$ (Debt Adjustment Act, or DAA), which is a court process.

If the consumer and the creditor have a disagreement related to the credit agreement, a consumer can apply for a settlement process involving the Consumer Disputes Board, which is a statutory alternative dispute-resolution organ (see the Act on the Consumer Disputes Board ${ }^{* 22}$ ). The Consumer Disputes Board is entitled to announce non-binding decisions on disputes between consumers and businesses. Another finance-related alternative dispute-resolution body is the Banking Complaints Board of the Finnish Financial Ombudsman Bureau (FINE), which handles only banking-related disputes. Both FINE and its Banking Complaints Board were established by the Federation of Finnish Financial Services, the Finnish Financial Supervisory Authority (FSA), and the Consumer Agency by mutual agreement.

\subsection{Instant-loan regulation: Key turning points}

The consumer-credit-related legislation has been revised several times. From the perspective of consumer credit-in particular, instant loans-there have been three main legislative amendments in recent years. These amendments are briefly introduced in this section of the paper, but they are dealt with more thoroughly in the following sections.

15 Luottotietolaki (Credit Information Act), 11.5.2007/527, as amended.

16 Korkolaki (Interest Act), 20.8.1982/633, as amended.

17 CPA, Chapter 17, Section 17 a.

18 Laki eräiden luotonantajien rekisteröinnistä (Act on Registration of Creditors), 27.8.2010/747, as amended.

19 Laki saatavien perinnästä (Debt Collection Act), 22.4.1999/513, as amended.

20 Laki talous- ja velkaneuvonnasta (Act on Financial and Debt Counselling), 4.8.200o/713, as amended.

21 Laki yksityishenkilön velkajärjestelystä (Act on the Adjustment of the Debts of a Private Individual), 25.1.1993/57, as amended.

22 Laki kuluttajariitalautakunnasta (Act on the Consumer Disputes Board), 12.1.2007/8, as amended. 
The first amendment to the CPA's Chapter 7, which entered into force in February 2010, established new obligations for consumer creditors, such as identification of the consumer and banning of night-time lending. In addition, the criminalisation of usury was revised to match the current conditions. These regulations are purely national-not based on EU-level directives.

Immediately after this, the comprehensive reform of Chapter 7 of the CPA entered into force in December 2010. The primary objective with this reform was the implementation of the EU Consumer Credit Directive (CCD), but still the previous amendments were preserved. The new Chapter 7 also includes regulations on good lending practice and the creditor's obligation for assessment of a consumer's creditworthiness. In addition, it established a supervision system and an obligation of registration for all consumer creditors. Consumer-credit agreements for under EUR 200 were beyond the scope of the CCD, but, because of the problems detected with instant loans, the reform of consumer-credit legislation was developed to cover all types of consumer credit. ${ }^{* 23}$

Thirdly, the most recent and most essential amendment, entering into force in June 2013, made provisions for a maximum annual percentage rate of charge allowed for a consumer credit. In addition, it specified an obligation of assessment of creditworthiness. These legislative changes too are completely national in nature.

\section{Registration of consumer-credit providers}

The Consumer Credit Directive's Article 20 requires that Member States ensure that creditors be regulated or be supervised by a body or authority independent from financial institutions. In Finland, this article was implemented by establishment of a system of registration of consumer creditors via the Registration Act. The Consumer Credit Directive itself does not require licensing or a registration system for consumer creditors, but in Finland, this solution was deemed necessary to ensure the reliability and professional qualifications of consumer creditors and to facilitate the supervision of the consumer lending business. ${ }^{{ }^{2} 4}$

Pursuant to the Registration Act, only a registered consumer creditor is eligible to engage in consumercredit business. ${ }^{* 25}$ The obligation to register does not, however, apply to institutions that are under the Finnish FSA's supervision, consumer creditors that finance only the acquisition of consumer goods they sell, the government, or a creditor from another EEA country who temporarily provides consumer credit in Finland. ${ }^{* 26}$

The registration of consumer creditors is not only based on notification; the creditor must meet the qualifications for registration under the law. The registration requirement for consumer creditors means, in fact, that consumer lending is a licensed business. ${ }^{* 2}$ First, a consumer creditor must meet the standard criteria to conduct business in Finland and not be the subject of bankruptcy proceedings. ${ }^{*} 8$ If the consumer creditor is a natural person, that person must also be of legal age, and that person's competence to enter into a contract must not be limited. ${ }^{*} 2$ Secondly, the special requirements for a consumer lending business are reliability and the necessary knowledge of the consumer lending business, ${ }^{*}{ }^{30}$ which are described in more detail below.

During the registration process, the registration authority will perform a reliability assessment, which means evaluation, from the reliability perspective, of all persons in charge of business, such as: ${ }^{*} 31$

- a private entrepreneur;

- the CEO and deputy CEO;

- the members and deputy members of the Board of Directors;

- the members of the supervisory board and corresponding members of the institution;

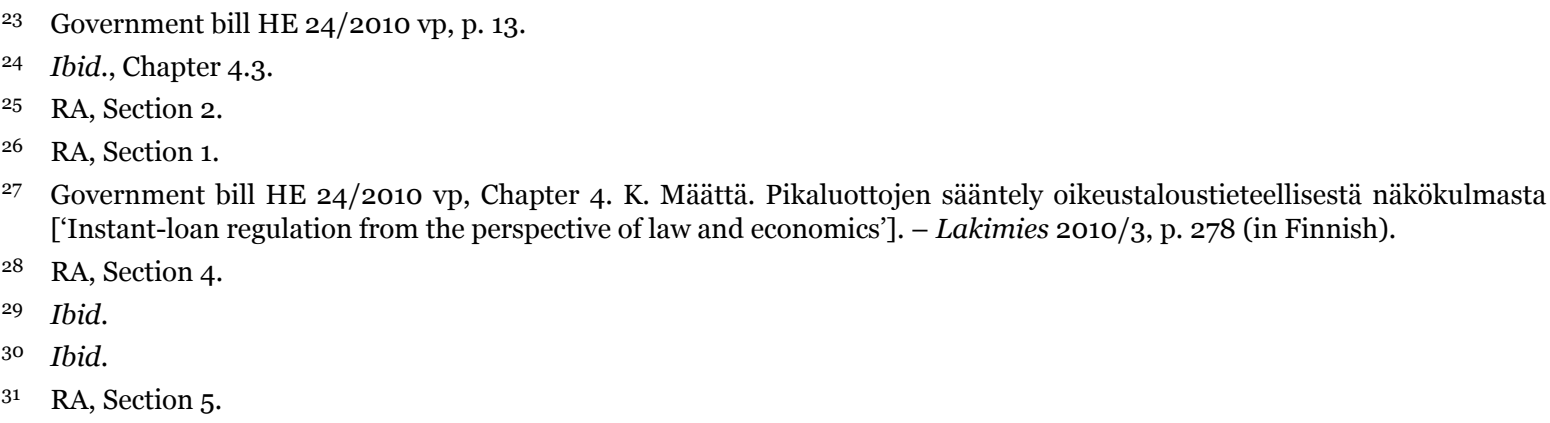


- general partners (in partnership companies);

- other members of senior management; and

- those who, directly or indirectly, own at least one tenth of the shares or voting rights or have comparable control of ownership.

A person shall not be considered reliable if he or she has been sentenced to imprisonment in the last five years or has within the past three years been sentenced to another penalty for a crime on account of which he or she may be considered to be unsuitable to hold a responsible position in a consumer lending company or act as a significant shareholder. ${ }^{*} 2$ Also not considered reliable is a person who otherwise has been proved by his or her past activities to be unsuitable for the corresponding task. ${ }^{*} 3$

The consumer creditor is required to possess the necessary knowledge of consumer lending, in view of the nature and extent of the consumer lending business. ${ }^{*} 34$ Only members of the creditor's senior management are required to meet the knowledge criteria. ${ }^{*} 35$ According to the government bill for the act, this means collective assessment: each member of the senior management need not have all of this knowledge; it is sufficient that the senior management as a whole fulfil the consumer lending knowledge requirements. ${ }^{*} 36$ Basically, one or some of the members of the senior management must meet all of these requirements. If the creditor also conducts other business than consumer credit, the requirement applies to those persons who are actually responsible for credit operations. ${ }^{*} 37$

The necessary knowledge of consumer lending is described in the government bill as knowledge of consumer-credit regulation, along with technical knowledge, skills, and complementary personal qualifications. Knowledge about consumer lending can be based on several years of practical work experience in the consumer lending business or appropriate education-for instance, an academic degree in business or law. The larger the consumer lending business, the higher the standards for the knowledge of consumer lending required. ${ }^{*} 38$

\section{Responsible lending}

\subsection{Background}

The Consumer Credit Directive does not actually set forth an obligation for the Member States to issue responsible lending standards in their legislation. The Consumer Credit Directive does, as a recommendation, encourage the Member States to promote responsible consumer lending practices. ${ }^{*}{ }^{39}$ Responsible lending, however, played a clearly stronger role in the preparation of the present directive. For example, in 2005 the Commission proposed that, in the provisions of the Directive, the creditor and credit intermediary would be required to comply with a specific principle of responsible lending. ${ }^{*} 40$ This requirement was not included in the final directive.

In Finland, there was seen to be an increasing need for provisions for responsible lending practices, not only because of the directive-based recommendation but also due to the fact that consumer lending had become more common, the supply of credit had increased, and new types of consumer credit (such as instant loans) had emerged. ${ }^{* 4}$ Consequentially, the Finnish legislator issued the provisions on good lending practice that took their place in the CPA's Chapter 7. Good lending practice was meant to refer to the general terms for consumer marketing, procedures in business-to-consumer relations, and prohibition of unfair contract terms. However, a special provision on good lending practice was necessary for reasons of clarity. ${ }^{*} 2$

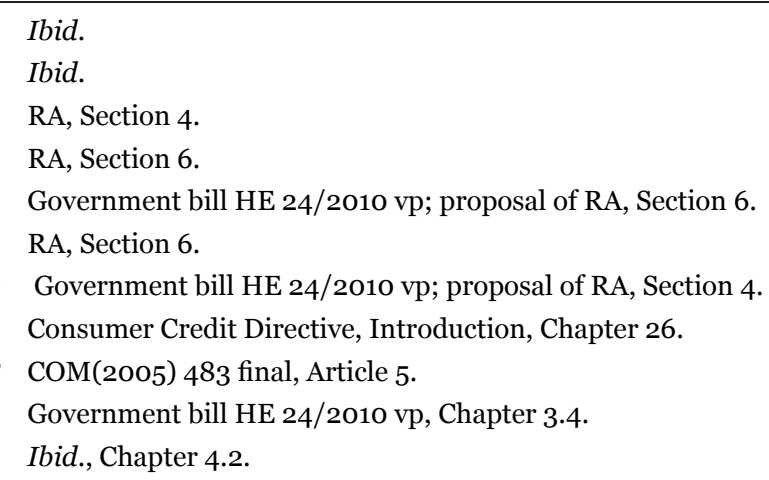


The provisions for responsible lending can be found in the CPA's Chapter 7 under the same subheading ('The Creditor's Duty of Responsible Conduct'). These responsible lending provisions are divided into good lending practice, obligation to assess the consumer's creditworthiness, and verification of the consumer's identity. ${ }^{*} 43$

\subsection{Good lending practice}

Consumer creditors are required to comply with good lending practice ${ }^{*} 44$ as an essential part of responsible lending obligations, accordingly:

The creditor shall act responsibly in lending.

It is required in particular that the creditor:

1) not market credit in manner that could clearly impair the consumer's ability to consider carefully whether or not to obtain the credit;

2) not use the granting of credit as the primary marketing method when marketing other consumer goods or services;

3) not collect additional fees and charges for text messages or other communication services in credit-marketing, credit-granting, or other customer service;

4) provide the consumer with sufficient and clear information prior to the conclusion of the credit agreement, for the consumer to assess whether the credit is suitable for his or her needs and financial situation; and

5) in situations of payment delay, provide the consumer with information and advice on how to prevent the occurrence or worsening of payment difficulties, manage situations of inability to pay, and take a responsible approach to payment arrangements.

The provisions laid down in Subsection 1 and Subsections 2(1-4) also apply to credit intermediaries. The provisions laid down in Subsection 2(4), however, do not apply to suppliers of goods or services that act as credit intermediaries in an ancillary capacity.

The legislative history points to the main purpose of good lending practice as being to prevent inappropriate lending practices and highlight the creditor's obligation to act openly and honestly, along with consideration for the interests and financial situation of the consumer. ${ }^{*} 45$ Good lending practice is intended to be a flexible legal norm, suitable for various types of consumer credit and changes in financial products, reinforcing the general consumer marketing and consumer relations provisions in the CPA's chapters 2 and 3, along with other consumer-credit regulations, in the CPA's Chapter $7 .{ }^{*}{ }^{46}$ The whole 'life cycle' of the consumer credit-from credit-marketing to debt-collection procedures and dispute resolution-should be subject to the obligations of good lending practice. ${ }^{*} 47$

In essence, the aim of good lending practice is to prevent consumers' over-indebtedness. The creditor shall not grant a loan when the applicant's financial situation does not indicate the ability to repay the loan. ${ }^{*} 48$ Under the CPA, the consumer creditor shall first assess the consumer's creditworthiness on the basis of the consumer's incomes and other sufficient financial information (see Subsection 3.3). Good lending practice, in practice, consists of following certain minimum financial requirements for granting of consumer credit. ${ }^{*} 49$

The minimum requirements for granting of a loan are not described in the law, but the government bill uses the credit-data register as an example for evaluation of the sufficiency of the consumer's financial situation. For instance, several payment defaults in the credit-data register may pose a hindrance to granting of credit, while a single payment default does not necessitate an absolute prohibition of lending. In the cases

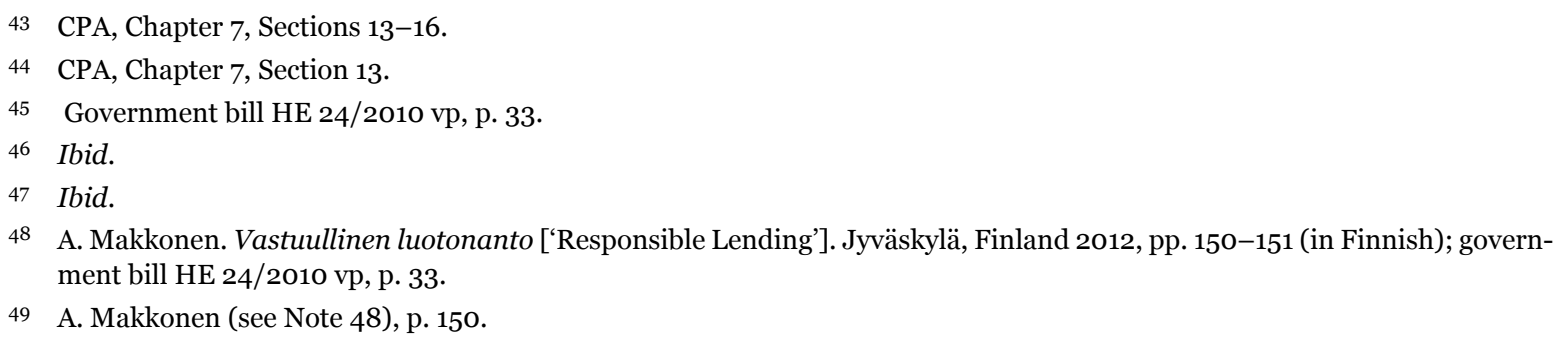


of default on payment, the creditor is obliged to take into consideration the number and the type of the payment defaults, alongside how recent the defaults are and the reasons for them. ${ }^{*} 50$

When taking into account the aim of good lending practice, one should not approach the question of the minimum financial requirements for the consumer only from the perspective of credit history; also the consumer's financial situation must be taken into consideration, as a whole. ${ }^{*}{ }^{11}$ As is explained in Subsection , Finnish credit-data registers include only information on payment default-they do not describe the consumer's financial situation overall. In addition, the obligation to assess a consumer's creditworthiness requires the creditor to conduct the evaluation of the consumer's financial situation by using information on income and other relevant financial matters. In this way, these two obligations-of creditworthiness assessment and good lending practice-must be applied as a whole.

Marketing that could impair the consumer's decision-making are expressly prohibited in line with good lending practice. ${ }^{*}{ }^{2}$ For example, marketing credit as a risk- and worry-free solution to financial difficulties, or by highlighting the instant access to credit while at the same time agitating toward ill-considered borrowing, does not comply with good lending practice. ${ }^{*} 53$ Furthermore, good lending practice rules out giving additional benefits or a lottery a dominant position in the marketing of credit products, and the same is true of offering additional interest or a discount on the condition that a product is bought on credit. ${ }^{*} 54$ The main message of credit marketing should be the credit itself and the features of the credit. ${ }^{*} 5$ It must be noted that the Consumer Protection Act uses the term 'marketing', which in the Finnish legal praxis means not only advertising but also other ways to provide information to the consumer and practices aimed at entering into a contract. ${ }^{*} 6$

Good lending practice requires that sufficient and clear information be disclosed to the consumer in support of the consumer's decision-making. ${ }^{*}{ }^{*} 7$ The creditor must provide adequate and clear explanations, to enable the consumer to assess whether he or she is able to fulfil the obligations of the credit contract and also evaluate which credit product would be the most appropriate. Moreover, additional information should be provided when requested by the consumer. ${ }^{*}{ }^{8}$ Standardised information for the consumer is not always sufficient, especially with more complex credit products and larger loan amounts. ${ }^{*} 59$

Applied over the entire life cycle of the credit relationship, good lending practice requires the creditor to disclose information, provide advice in cases of payment difficulties, and have a responsible approach toward payment arrangements. ${ }^{*}{ }^{* 0}$ The creditor's obligations in payment difficulty situations are addressed in Section 5 .

The provision on good lending practice was updated in June 2013 with a prohibition of collecting additional costs related to marketing of credit, loan applications, or customer service. This provision prevents only these additional costs' collection by the creditor-the consumer is still obliged to pay, for example, the phone operator's fee for the call. ${ }^{*}{ }^{1}$ This amendment is linked to regulation of maximum rates, aimed at preventing adding extra costs to consumer credit in other ways. Maximum interest rates' regulation is explained in more detail in Subsections 6.1-6.3.

\subsection{Assessment of creditworthiness}

Another essential part of responsible-lending-based obligations is that of assessing the consumer's creditworthiness, which is a mandatory action for consumer creditors under the CPA. Prior to entry into a credit agreement, the creditor is obliged to evaluate whether the consumer can fulfil the obligations of

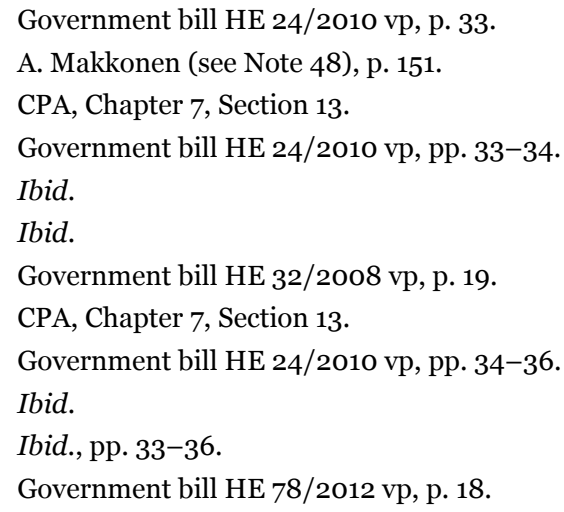


the credit contract. ${ }^{*} 62$ The creditworthiness assessment shall be conducted on the basis of all sources of the consumer's income as well as other sufficient financial information. ${ }^{*} 63$

In the legislative history, the function of the creditworthiness assessment obligation has been described more extensively. The key factor is verifying that the consumer's financial situation is sufficient in relation to the credit obligations by using a credit-data register, ${ }^{*} 64$ which is generally considered an integral part of professional consumer lending. While this information does not in itself detail the consumer's overall financial standing, it does indicate whether the consumer has been in serious default on payment. ${ }^{* 6}$ Granting a loan without checking the credit history would be possible only in exceptional circumstances, notably in the situation wherein the creditor is already familiar with the consumer's financial background on the basis of their prior customer relationship.. ${ }^{*} 66$

Determining the consumer's credit history or using a credit-scoring system is not sufficient on its own for fulfilling the obligation of a creditworthiness assessment. According to the legislative history, the creditor is also obliged to evaluate the consumer's actual ability to repay the loan. Therefore, creditworthiness must be assessed not only on the basis of the consumer's income (that is, all income received by the consumer) but also in view of the type(s) of income involved. Subsequently, types of income such as salary and pension, as well as expenditures, debts, assets, and other property, must be taken into consideration, along with a determination of whether the consumer is already a guarantor. The creditor should also take into account any factors affecting the continuity of income, such as whether the consumer's employment is fixed-term or permanent. Furthermore, the factors that may effect an increase of expenditure, such as the risk caused by rising interest rates, should be included in the overall evaluation. ${ }^{* 67}$

The requirement of a creditworthiness assessment applies for small consumer loans too. ${ }^{* 68}$ However, the extent of the creditworthiness assessment also depends on the amount of the consumer credit; the higher the amount, the more thorough the procedure and the more the financial information needed. ${ }^{*} 69$ For example, analysing the effects of possible rising interest rates is relevant only for larger loan amounts and longer loan periods-as in the case of housing loans.

Furthermore, it is required that the creditor not use only, for example, 'checkboxes' on the loan application forms and Web pages when collecting information related to the consumer's financial standing. The creditor should also reasonably ensure that the information given by the consumer is true and correct, by, for example, requesting additional documentation on income sources (salary, pension, etc). ${ }^{*} 70$

\subsection{Verification of a consumer's identity}

The third part of the responsible lending provisions under the CPA is a creditor's obligation to verify the consumer's identity and to retain the verification data. ${ }^{* 1}$ This was included in the first amendment pertaining to instant loans, which came into force in February 2010. The purpose of the provision is to prevent delinquency in consumer lending, especially for situations wherein a false identity is used when one is applying for credit. ${ }^{*} 72$ In addition, the personal-data legislation reinforces this obligation, as was held in a Supreme Administrative Court case wherein granting a loan without verifying the loan applicant's identity was deemed contrary to the general principles of personal data's protection under the Personal Data Act. ${ }^{*} 73$

62 CPA, Chapter 7, Section 14.

63 Ibid. The provision on creditworthiness assessment came into force in December 2010 and was revised in June 2013. The original provision required creditworthiness assessment on the basis of sufficient information on the amount of credit and other circumstances. The main reason for the reform was that a creditworthiness assessment obligation was seen as appropriate also in cases of consumer loans for smaller amounts, such as instant loans. See government bill HE 78/2012 vp, p. 11.

64 Government bill HE 24/2010 vp, pp. 35-36; government bill HE 78/2012 vp, pp. 18-19.

65 Government bill HE 241/2006 vp, p. 12.

66 Government bill HE 24/2010 vp, pp. 35-36; government bill HE 78/2012 vp, pp. 18-19.

67 Ibid.

68 Ibid.

69 Ibid.

70 Ibid.

71 CPA, Chapter 7, Sections 15-16.

72 Government bill HE 64/2009 vp, pp. 20-22.

Case KHO (referring to the Supreme Administrative Court) 8.1.2010, No. 1568/1/o9. 
According to the CPA, the creditor is obliged to take care to verify the consumer's identity prior to entry into a credit agreement. ${ }^{*} 74$ If the creditor verifies the consumer's identity electronically, the identification method used must meet the requirements stated in the Act on Strong Electronic Identification and Electronic Signatures. ${ }^{*} 75$ On a practical level, these requirements mean that the verification methods permissible are an official identification document (such as a passport, driver's licence, or identity card issued by the government) and strong electronic identification such as an officially issued electronic identity card, online banking credentials, or a mobile certificate that meets the applicable standards of the law. Once the identity verification has been initially conducted by means of an official identity document or strong electronic identification, the consumer's identity may thereafter be verified via a personal identifier-for instance, a consumer-specific PIN code. ${ }^{*} 6$

\section{Regulations on credit data}

\subsection{The general principles of credit-data regulation}

The Credit Information Act ${ }^{*} 77$ regulates issues related to the use of credit data. According to the CIA, 'credit data' refers to information that is intended to indicate ability to pay, a willingness to pay, or other relevant financial information. ${ }^{*} 78$ It is essential to note that the CIA covers not just credit information from business and credit-data registers but also all data detailing the party's financial standing, such as information on income sources, expenditures, financial commitments, and corresponding information. Accordingly, the CIA applies to the entire creditworthiness assessment process and is not limited to issues related to credit-data registers.

The CIA regulates requirements and restrictions on credit data that the creditor is obliged to follow when granting or controlling credit. Therefore, the provisions of the CIA must be applied in conjunction with the obligation of creditworthiness assessment as regulated in the CPA. It can be concluded that the CIA limits in a certain way the information that a creditor is entitled to utilise in the credit-granting process. On the other hand, the guiding principle of the CIA is that the credit assessment must be carried out by means of necessary and relevant information. ${ }^{*} 9$ On a practical level, this means that the CIA does not necessarily set restrictions on utilising relevant information that objectively describes the consumer's financial standing.

When handling credit data, the creditor is obliged to comply with good credit-data practice. This requires that credit data be handled carefully, that the quality of the credit data be ensured, and that disclosure obligations and data security be maintained. Furthermore, the data must be kept secure in a proper and appropriate manner, and the internal supervision for proper handling of credit data must be ensured. An important principle to be upheld is that the customer has the right to be evaluated only on the basis of relevant and accurate information. ${ }^{*} 80$

The CIA provides more detailed requirements regarding credit data's quality and information sources that the creditor is allowed to use. Only necessary and relevant financial information may be used in the credit-granting process. The creditor is entitled to obtain credit data directly from a credit-data register, an appropriate official register, or the creditor's own customer database. Other credit data shall be obtained only with the consumer's consent. ${ }^{*} 81$

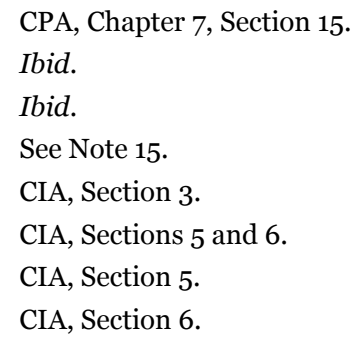




\subsection{The information provided by credit-data registers}

Finnish credit-data registers covering individuals are based on negative credit information, which means information on payment default. The credit-data legislation does not allow registering positive credit information-in other words, information on outstanding debts and other financial commitments. Legislative actions related to a positive credit-data register were recently considered, but the report ${ }^{*} 82$ on the legal background recommended that new credit-information legislation not be initiated yet, because of, for instance, the forthcoming personal-data regulation at the EU level intended to harmonise the personaldata legislation of all $\mathrm{EU}$ member states.

The CIA includes provisions on requirements for the credit-data business, ${ }^{*} 83$ entries in credit-data registers ${ }^{*} 84$, and retention periods for register entries ${ }^{*} 85$. Credit-data registers are non-public and maintained by privately held businesses. ${ }^{*} 86$ The CIA merely sets restrictions and limitations for using and collecting credit data, which means that the minimum coverage of a credit-data register is not regulated. In practical terms, the coverage of the credit-data register is also a business question for the provider of credit data; therefore, credit-data providers usually intend to maximise the information contained in the register.

A credit-data register essentially consists of information included in several official registers, but the information sources also include the creditors and the consumers themselves. Accordingly, a credit-data register collects information on payment default from several sources and consolidates this into a single register. ${ }^{*} 7$ Credit-data-register information on private persons is restricted and is to be used only for purposes that are permissible under the CIA, such as consumer lending. However, it is important to note that most of the credit information included in official source registers, such as court registers and enforcement registers, is public-even when the information pertains to private persons.

Credit-data registers include a wide range of information, from diverse judicial processes related to default on payment. The enforcement process for private debts is divided into two phases in Finland: the creditor must firstly claim the receivable in a court procedure ${ }^{* 88}$ prior to the debt-enforcement process. The credit-data registers include information on both of these phases: the court decisions on debts and also on long-lasting debt-enforcement processes and lack of assets and possessions on the debtor's part. Information on other debt-related court proceedings-namely, a private person's debt adjustment, business restructuring, and bankruptcy-can also be entered in a credit-data register.

When a private person's debt adjustment is based on an agreement between the debtor and the creditors instead of court proceedings, a credit-data-register entry pertaining to the contract is possible, but only the debtor is entitled to apply for this registration. ${ }^{*} 89$ The requirements state that the debtor must confirm the payment default and the debt arrangement must concern several creditors, or the arrangement must otherwise be extensive. ${ }^{*}{ }^{\circ}$ On a practical level, creditors usually require the credit-data-register entry before entering into a debt-adjustment agreement. ${ }^{*} 1$

The creditor is entitled to report an overdue payment to the credit-report register only if the payment is at least 60 days overdue and the possibility of a credit-data-register entry is specified in the terms and conditions

82 A. Saarenpää. Näkökohtia luottotietojen kokoamisen ja käytön sääntelystä ['Perspectives on the Regulation of Gathering and Using of Credit Information']. Ministry of Justice, Reports and Guidelines 22/2013.

83 CIA, Chapter 3.

84 CIA, Sections 12-15.

85 CIA, Section 18.

86 There are currently two credit-data-register companies in Finland: Suomen Asiakastieto Oy and Bisnode Finland Oy (the latter provides credit information via the Soliditet credit-data register).

87 A. Makkonen (see Note 48), p. 99.

88 The most common court procedure related to debts with a specific sum, based on a contract, a commitment, or other written evidence, is the summary procedure, which can be used when the matter is not under dispute. It is more straightforward than the regular civil procedure: only a brief application for summons is required, and the creditor is not obliged to attach written evidence to the application. As in all civil procedures, the court will notify the debtor about the procedure in written form, and if the debtor does not submit a defence to the court within the given time, the court will pass judgement in favour of the creditor-unless the creditor's claim is clearly without basis. However, if the creditor's claim turns out to be unclear or under dispute, the case shall be transformed into a regular civil procedure. See the Code of Judicial Procedure ('oikeudenkäymiskaari'), 4/1734 (as amended), Chapter 5.

89 CIA, Section 13.

90 Ibid.

$91 \quad$ A. Makkonen (see Note 48), p. 110. 
of the credit agreement. In addition, the creditor is required to send an appropriate notice to the debtor with 21 days' notice prior to entry in the register. It is important to note that entry in the credit-data register is not possible when the debtor and creditor have agreed on a new payment schedule for the outstanding debts. ${ }^{*} 2$

In addition to payment-default information, the credit-data register can include information pertaining to contract-related competence, to ensure the legal competence of the person. The source is the public guardianship register, maintained by the local register offices of Finland. ${ }^{*}{ }^{9}$

A person may also apply for a credit-data register entry for 'own credit stoppage, ${ }^{*}{ }^{94}$ usually with the purpose of preventing the financial consequences of identity theft, such as use of a false identity when one is applying for credit. ${ }^{*} 95 \mathrm{~A}$ reason for such a credit-data-register entry need not be given, and the register provider must allow the entry upon receiving the application. Conversely, the register entry may be removed at any time. This register entry is intended to constitute additional information for the purpose of greater prevention of the risk of identity theft.

From the legal perspective, the 'own credit stoppage' does not cause invalidity of credit agreements or other contracts. Consumer creditors are, however, obliged to comply with good lending practices overall with regard to the consumer-credit relationship and the credit-granting process. From this perspective, the creditor's reasonable obligation would be that the consumer's identity must be protected and, therefore, verified with a caution commensurate with the best practices generally available. In practice, some consumer creditors tend not to grant loans via electronic means when the consumer has an 'own credit stoppage. ${ }^{*}{ }^{9} 6$

The retention periods for credit-data-register entries are 2-5 years, depending on the type of the credit-data-register entry. ${ }^{*}{ }^{97}$ Register entries are generally not removed upon the debt's repayment, but the debtor may submit a notification in the form of supplementary information. ${ }^{*}{ }^{8}$ The debtor may also submit additional relevant information pertaining to debts-for instance, detailing the reasons for a payment default. In some cases, the debt's repayment may shorten the retention period.

Use of a private person's credit information is limited to only specific situations. In consumer lending, the main situations in which this is permissible are credit-granting, credit control, and debt-collection planning. ${ }^{*} 99$ Outside these purposes, using any credit-data information-including credit-data registers and other credit details-is not possible. The consumer must be informed of the use of a credit-data register in advance of the application for credit. ${ }^{*} 100$

\section{Regulation of the consumer's payment difficulties}

\subsection{Responsible lending and good debt-collection practice}

As is mentioned in Subsection 3.2, above, good lending practice requires the creditor to provide information and advice in situations of payment difficulty, and it requires the creditor to approach payment arrangements in a responsible manner.

Firstly, good lending practice requires creditors to advise consumers and disclose additional information related to payment difficulties. It has been stated in the legislative history that it is required that the creditor encourage the consumer to contact the creditor in situations of payment delay and supply relevant information about the authorities that provide debt counselling. In addition, the creditor must provide information about the arrangements for debts, along with the possible consequences of delayed payment, such as termination of the credit agreement, late-payment interest, debt collection, and payment-default entries in credit-data registers. In practice, this information can be provided, for example, in connection

92 CIA, Section 14.

93 CIA, Section 12.

94 CIA, Section 12.

95 In practice, it is usual that 'own credit stoppage' is also used to prevent over-indebtedness.

96 A. Makkonen (see Note 48), pp. 157-158.

97 CIA, Sections 17-18.

98 CIA, Section 13, Subsection 2.

99 CIA, Section 19.

100 CIA, Section 29, Subsection 2. 
with payment reminders. Nonetheless, information about possible consequences of payment delays must not be misleading or exaggerated. Guidelines on good debt-collection practice require that the consumer be informed only of the likely consequences of certain payment-default situations. ${ }^{*} 101$

Secondly, good lending practice requires the creditor to maintain a responsible approach to payment arrangements. According to materials forming part of the legislative history, this does not oblige the creditor to agree to all of the proposed arrangements for payment, but the systematic refusal of payment arrangements should be considered contrary to good lending practices. Possible debt arrangements might be, for instance, a new due date for the payments, reduction of the monthly payments, extension of the loan term, aggregation of several separate loans, instalment-free periods, and the reference rate's modification to reduce the interest rate. The creditor is still allowed to assess whether the arrangement is reasonable under case-specific circumstances and is encouraged, when possible, to seek a conciliatory solution in collaboration with the consumer. ${ }^{* 102}$

In addition to good lending practice, the creditor is obliged to comply with good debt-collection practice, which also includes an obligation to approach the payment arrangements in a responsible manner. During the debt-collection process, false or misleading information on the consequences of payment delays is prohibited, as is causing unreasonable or unnecessary costs or harm or jeopardising the debtor's right to privacy. It is contrary to good debt-collection practice to attempt to collect a time-barred or otherwise invalid debt. ${ }^{* 103}$

\subsection{Financial and debt counselling}

In Finland, financial and debt counselling is a government-based, charge-free service for private persons that is based on certain legislative acts and overseen by the Competition and Consumer Agency. Financial and debt counselling is intended to prevent over-indebtedness of private persons by providing advice on payment difficulties and assisting them in solving their various debt problems. The Regional State Administrative Agencies entitle service providers-which can be public authorities such as municipalities, social and health departments, and religious congregations, along with private (profit or not-for-profit) organisations, to provide these services. Financial advisers who work for certified financial- and debt-counselling providers are entitled to assist their clients in a private person's debt-adjustment process when there has been a court filing. ${ }^{*}{ }^{* 104}$

\subsection{Adjustment of private debts}

The adjustment of private debts is a court process applied for by the insolvent private person. It can be characterised as among general insolvency proceedings, as it encompasses all of the debtor's debts and other outstanding financial commitments, such as guarantees. After the court has determined that the debtor fulfils the requirements for debt adjustment, the court is entitled to confirm a new payment schedule for the outstanding debts, which may include, for instance, making reductions in the total amount of the debt (except in cases of secured loans); reducing interest rates, and adjusting the provisions for liquidating the debtor's assets and possessions. ${ }^{*} 105$ Usually the payment schedule for the debt adjustments covers $3-5$ years, depending on the debtor's situation. ${ }^{*}{ }^{106}$ If the debtor's income increases during this time, the debtor is obliged to pay an additional amount correspondingly. ${ }^{*}{ }^{* 107}$ Once the debtor successfully fulfils the obligations set forth in the payment schedule, the debts and financial commitments specified through the debt adjustment no longer apply. ${ }^{*} 108$

101 CPA, Chapter 7, Section 13; government bill HE 24/2010 vp, pp. 33-36; DCA, Section 4; government bill 199/1996, Chapter 2.1; Competition and Consumer Authority guidelines 'Good Debt-Collection Practice in Consumer Relations' (i.e., Hyvä perintätapa kuluttajaperinnässä), p. 5 .

102 CPA, Chapter 7, Section 13; government bill HE 24/2010 vp, pp. 33-36.

103 DCA, Section 4.

104 Laki talous- ja velkaneuvonnasta (Act on Financial and Debt Counselling), 4.8.200o/713, as amended.

105 DAA, Section 34.

106 DAA, Section 30.

107 DAA, Section 35 a.

108 DAA, Section 40. 
The requirements of a private debt adjustment are judged from need and social circumstances. The first requirement is that the applicant be permanently insolvent, which means permanent inability to fulfil the financial commitments. ${ }^{*} 109$ The debt-adjustment process is not possible in cases of temporary payment difficulties that are due, for instance, to short-term unemployment. The second requirement for debt adjustment is the debtor's social circumstances: illness, inability to work, long-term unemployment, or other change in circumstances that fundamentally reduces payment ability. ${ }^{{ }^{110}}$ It must also be proved that the over-indebtedness is not primarily the debtor's own fault. ${ }^{* 111}$

However, there are circumstances that may prevent the approval of the private debt-adjustment process. These may involve criminal or improper behaviour of the debtor, such as an irresponsible approach to financial commitments; arrangements that have weakened the position of creditors; false or misleading information given in credit-granting or insolvency proceedings; hiding of assets, property, or income; or crime-based over-indebtedness. ${ }^{*}{ }^{112}$ Notwithstanding the above-mentioned factors, private debt adjustment can be exceptionally granted for weighty social reasons. ${ }^{*} 113$

A debt-adjustment procedure can later be cancelled by court decision. Reasons for cancelling debt adjustment include significant breach of the payment schedule by the debtor without justifiable reason, a pre-existing reason for denying the whole debt-adjustment process, the debtor endangering the payments by taking on new debt that is not based on need, and the debtor otherwise failing to co-operate in the debt-adjustment procedure. Once the debt-adjustment procedure is cancelled, the original terms and amounts of the debts will revert to the form they would have had originally without the debt adjustment. Interest on late payment does not accumulate during the duration of the debt adjustment, unless the court orders otherwise. ${ }^{* 114}$

A reform of the Act on the Adjustment of the Debts of a Private Individual is currently pending. The working group, appointed by the Ministry of Justice, suggests that a creditor's actions must also be taken into consideration in determination of the requirements for the debt-adjustment process. ${ }^{*} 15$ The especially key issues would be good lending practice and the obligation to generate a creditworthiness assessment. ${ }^{*}{ }^{116}$ For instance, if the creditor is responsible for aggressive credit-marketing, has otherwise operated contrary to good lending practice, or has neglected the obligation of a creditworthiness assessment, entry into a debt-adjustment procedure may be granted as a result. This reform would likely encourage creditors to be careful to comply with good lending practice and the creditworthiness assessment obligation. On the other hand, the proposal can be criticised in cases wherein only some members of a group of creditors have acted counter to the responsible lending provisions, thus placing an undue burden upon those creditors who did comply with the applicable legal requirements.

\section{The limitations to credit costs and the accessibility of credit}

\subsection{Regulation of credit prices}

The provision pertaining to the maximum total cost for consumer credit-a so-called interest-rate capentered into force in June 2013 and is included in the CPA's Chapter 7. In cases wherein the consumer credit amounts to less than EUR 2,00o, the actual annual percentage rate of interest must not exceed the reference rate under Section 12 of the Interest Act plus 50 percentage points. ${ }^{*} 117$ When calculating the annual percentage interest rate, one must take into account the interest on the credit and the other credit costs

\footnotetext{
09 DAA, Section 9.

110 Ibid.

111 Ibid.

112 DAA, Section 10.

113 DAA, Sections 9 and 10 a.

114 DAA, Section 42.

115 Ministry of Justice (Oikeusministeriö). Velkajärjestelylain tarkistaminen ['The revision of [the] Debt Adjustment Act']. Reports of the Ministry of Justice (or 'Oikeusministeriö, mietintöjä ja lausuntoja') 59/2013, pp, 84-85 (in Finnish).

116 Ibid.

117 CPA, Chapter 7, Section 17 a.
} 
charged to the customer. ${ }^{*} 118$ The interest-rate cap applies to all types of credit, including both runningaccount credit and lump-sum credit, with the exception of goods-or-services-related credit.

The reference rate under the IA's Section 12 is semi-annual and uses the European Central Bank (ECB)'s main refinancing-operations rate, rounded up to the nearest half-point. The Bank of Finland regularly publishes the reference rate. ${ }^{*}{ }^{* 19}$ As of this writing, the reference rate (for the period 1 January-30 June 2014) is $0.5 \%$ and the interest-rate cap is $50.5 \%$.

\subsection{Interest for late payment}

The Interest Act includes provisions on the maximum interest for late payment in cases wherein the debtor is a consumer or the debt has to do with housing rent. Higher interest for late payment, along with commissions, fees, or similar payments that are intended to act as a substitute for the interest on late payment, cannot be applied under the law. ${ }^{* 120}$

The annual interest rate for late payment shall not exceed the reference rate referred to in the Interest Act's Section 12 plus seven percentage points, ${ }^{, 121}$ which is the statutory late-payment interest. At the time of the writing of this article, the statutory maximum late-payment interest rate (for 1 January to 30 June 2014) is a total of 7.5\%.

For many types of unsecured consumer loans, the original interest rate is well above the maximum interest allowed for late payment. In these cases, the creditor is still entitled to collect interest at the original rate and costs agreed upon in the credit agreement instead of the statutory late-payment interest. However, the original interest rate and costs may only be charged for up to 180 days after the total debt is fully due, and the maximum statutory late-payment interest thereafter. If the creditor has claimed the debt through a court process, the creditor is entitled only to the statutory late-payment interest from the court decision onward. ${ }^{*}{ }^{122}$

\subsection{Regulation of debt-collection costs}

Pre-judicial-procedure debt-collection actions, by, for example, a debt collection agency, shall be carried out under the Debt Collection Act. The DCA includes provisions for limits to debt-collection costs, because excessively high costs have been determined to exacerbate consumers' over-indebtedness problems. ${ }^{*}{ }^{123}$ Debt collection is an essential part of instant-lending activities, especially on account of the large proportion of payment defaults. Some of the debt-collection agencies are part of the same financial entity (such as a corporate group) as the creditor. ${ }^{*} 124 \mathrm{~A}$ reform to the regulation of debt-collection costs took place in March 2013, when the legislator significantly decreased the maximum costs allowed for debt collection. The main reasons for the reform were the greater cost-efficiency now possible in debt-collection processes (thanks to, for example, development of data systems) and problematically high debt-collection costs. ${ }^{{ }^{1} 25}$ Furthermore, high debt-collection costs have been widely noted by various media. ${ }^{* 126}$

The maximum limit for the debt-collection costs depends on the amount of the debt. For the same debt, the creditor-or the debt-collection agent-is allowed to charge the consumer no more than EUR 60 for debt amounts up to EUR 100, EUR 120 when the amount of the debt is at least EUR 100 but not less than EUR 1,000, and EUR 210 if the amount of the debt is more than EUR 1,000. ${ }^{* 127}$

118 CPA, Chapter 7, Section 6.

119 IA, Section 12 a.

120 IA, Section 2.

121 IA, Section 4.

122 Ibid.

123 Government bill HE 57/2012 vp, Chapter 3.5.

124 Ibid., p. 18.

125 Research into debt-collection costs indicated that in many cases the debt-collection agencies did not comply with the recommended maximum total collection costs specified in the guidelines for good lending practice. See government bill HE 57/2012 vp, p. 28.

126 Debt-collection costs have even been a topic of the popular television documentary series MOT ('Rahastusta velkakierteellä'), presented on the television channel YLE TV1 on 8.9.2008 and available also at http://yle.fi/elavaarkisto/artikkelit/rahastusta_velkakierteella_35891.html\#media=35897 (most recently accessed on 12.4.2014) (in Finnish).

127 DCA, Section $10 \mathrm{~d}$. 
However, the debtor is allowed to collect the actual costs in exceptional cases. This basically applies to situations in which the debt collection has been difficult, with consideration for the fact that the debt-collection acts undertaken would not be considered disproportionate, particularly with regard to the total amount of the debt in question. In these situations, it is required that the debtor discloses a detailed calculation of the debt-collection costs and the reasons for the higher costs. ${ }^{*}{ }^{128}$

A court procedure is an obligatory phase before the legal-enforcement process. The maximum total court costs (in addition to debt-collection costs) that the creditor is able to claim from the debtor in summary procedures are-depending on the circumstances-usually EUR 115-166 (when the capital amount of the debt is up to EUR 300), EUR 145-206 (when the capital amount of the debt is at least EUR 300 but does not exceed EUR 1,000), or EUR 175-246 (if the amount of the debt is more than EUR 1,000). ${ }^{*}{ }^{129}$

\subsection{Usury}

Levying of clearly disproportionate costs for credit is sanctioned as usury under the Criminal Code. The provision pertaining to usury was reformed in the first instant-loan regulation package, coming into force on February 2010. According to the Criminal Code, a person shall be sentenced for usury:

who takes or requires for himself or herself or another, an interest or other economic benefit that is clearly disproportionate to the performance of the creditor, taking into consideration:

(1) the amount of credit granted, the period of credit and the other terms of the credit agreement;

(2) the credit risk involved in the credit that has been granted;

(3) the expenses incurred by the creditor that are part of the careful procedure for the granting of credit;

(4) the ordinary expenses incurred in the financing of the credit;

(5) the ordinary general expenses in credit granting services. (Chapter 36, Section 6)

As the wording of the Criminal Code indicates, even clearly disproportionate costs of credit fulfil the essential elements of usury-exploiting the debtor's predicament is not required. It is stated in the legislative history that all costs of the credit shall be taken into consideration, including the interest rates, fees, and commissions, along with other than monetary economic benefits, such as objects and possessions that have financial value. ${ }^{* 130}$ However, corporate criminal liability does not apply in cases of usury. Only the management may be convicted.

It has been stated that the reform of the usury statute would have reduced the costs of instant loans. Some of the instant-loan companies were noticed to have changed their credit-cost policy in line with the examples articulated in the legislative history. ${ }^{*}{ }^{131}$ Moreover, an observation was made that the obligation to verify customers' identity and the regulation pertaining to the actual percentage rate were put into practice among creditors. Comprehensive studies have not been done, however. The examples cited above are mainly from random observations. ${ }^{*} 132$

Sentencing for usury in credit-granting situations is very rare in Finland-the most recent cases related to usury that came before the Supreme Court were in the 1950 os. ${ }^{*} 133$ However, after the renewal of the usury provision, the Consumer Ombudsman filed a report of an offence involving alleged usury in an instant-loan business, which recently led to prosecution of the chief executive officer of the creditor company. ${ }^{*} 134$ In fact, the provision pertaining to usury can be considered unclear, especially in its definition of clearly dispro-

128 DCA, Sections $10 \mathrm{a}, 10 \mathrm{c}$, and $10 \mathrm{~d}$.

129 Ministry of Justice decree 14.12.2001/1311, as amended; government decree 19.12.2013/1058.

130 Government bill HE 64/2009 vp; proposal of the Penal Code, Chapter 36, Section 6.

131 Ibid.

${ }_{132}$ See J. Tapani. Kiskontarikokset: luottokiskonta ['Criminal usury: Credit usury']. - Lakimies 2010/4, p. 528 (in Finnish).

133 Ibid., p. 518.

134 Bulletin of the Consumer Agency 'Poliisille tutkintapyyntö koronkiskonnasta' ['A report of an offence related to usury'], available at http://www.kuluttajavirasto.fi/fi-FI/arkisto2010/verkkolehti-7-2010/poliisille-tutkintapyynto-kiskonnasta (most recently accessed on 6.4.2014) (in Finnish); 'Pikavippifirman pomo saa kiskontasyytteen' ['A boss of an instant-loan company accused of credit usury'], an article on the Web site of the newspaper Helsingin Sanomat, available at http://www.hs.fi/ talous/a1363834412174 (most recently accessed on 6.4.2014) (in Finnish). The district court dismissed the charges in late July 2014 (at the time of writing, however, the decision may still be appealed). 
portionate costs of credit. This may be one reason that prosecution and sentencing for usury are very rare. On the other hand, it would seem that the existence of a usury-related provision in the first place has had some preventive effects in the credit business.

\subsection{Limitations on night-time credit accessibility}

The first regulative package related to instant loans, which came into force in February 2010, included provisions for limitations to night-time credit-granting. This is purely national, non-harmonised legislation. Night-time granting of instant loans was considered a potential risk for imprudent loan applications, causing more indebtedness problems for consumers. ${ }^{*} 35$ However, prior to the legislative actions, night-time lending was regarded as being against the general provisions on consumer marketing and consumer relations under the CPA's chapters 2 and 3, based on the decision of the Market Court in 2009. ${ }^{*}{ }^{136}$

When credit is both applied for and granted between 11pm and 7am Finnish time, the amount of credit is not permitted to be dispensed to the consumer until 7am following the loan's approval. ${ }^{*} 37$ Accordingly, if the credit had been applied for before 11pm, the amount of the credit is permitted to be dispensed to the consumer also during the night without restrictions. The law does not restrict submission of a loan application in such a manner; the consumer is permitted to apply for credit regardless of the time.

The restriction to dispensing of the credit amount applies only to new credit agreements, not to credit limits. According to the legislative history, this exception was seen as appropriate so as not to prohibit increasing a credit-card limit when the consumer is abroad in another time zone. ${ }^{*}{ }^{*}{ }^{8}$ Moreover, the law does not set any restrictions to the use of credit cards, credit accounts, or other credit limits. ${ }^{*} 139$

\section{Supervision}

\subsection{Supervisory authorities}

Several authorities supervise the consumer-credit business. According to the CPA, the Consumer Ombudsman monitors compliance with the general provisions for consumer marketing and the terms and conditions of business-to-consumer-related agreements. ${ }^{*}{ }^{140}$ Furthermore, the Consumer Ombudsman and the Finnish Competition and Consumer Authority, along with its subsidiary Regional State Administrative Agencies, supervise compliance with the CPA's Chapter 7. ${ }^{*} 141$ The Finnish Financial Supervision Authority supervises banks and other credit institutions.

In practice, the Consumer Ombudsman and the Competition and Consumer Authority can be considered a single authority, because the Consumer Ombudsman acts as director-general of consumer affairs for the Competition and Consumer Authority. ${ }^{*} 142$ The Consumer Agency and the Competition Authority merged into the Competition and Consumer Authority at the start of 2013. Because of the merger of these authorities, the law expressly provides an independent position for the Consumer Ombudsman in a consumer-protection-related supervisory capacity. ${ }^{*} 43$

The Regional State Administrative Agency of Southern Finland, which maintains the consumer-creditor register, is also an important supervisory authority for consumer creditors. The agency's duties are to make decisions pertaining to consumer-creditor registration and to supervise consumer creditors' compliance with the provisions of the Registration Act. As was mentioned in Section , above, consumer creditors are required under the RA to have a legal right to conduct business in Finland, sufficient reliability, and the

135 Government bill HE 64/2009 vp, p 17.

${ }_{136}$ Case MAO (referring to the Market Court) No. 257/09.

137 CPA, Chapter 7, Section 19.

${ }_{138}$ Government bill HE 64/2009 vp, p. 18.

139 Ibid., p. 25.

140 CPA, Chapter 2, Section 20 and Chapter 3, Section 4.

141 CPA, Chapter 7, Section 51.

142 Laki Kilpailu- ja kuluttajavirastosta (Act on the Competition and Consumer Authority), 30.11.2012/661, Section 3.

143 Act on the Competition and Consumer Authority, Section 4. 
necessary knowledge of consumer lending. In addition, the Registration Act expressly requires that the consumer creditor comply with good lending practice and with other legal requirements related to consumer lending. ${ }^{*}{ }^{144}$ In point of fact, this widens the supervisory duties of the agency toward general supervision of the lending business-such supervisory duties are not limited to only registration requirements. The supervision conducted by the agency actually overlaps with that of the consumer authorities.

The division of supervision between the Regional State Administrative Agency of Southern Finland and consumer authorities (the Consumer Ombudsman and the Competition and Consumer Authority) is not clear from the law, on account of a lack of provisions clearly specifying which body is the primary supervision authority. According to the Registration Act, the supervisory role of the Regional State Administrative Agency of Southern Finland can be considered independent, but in the governmental structure, the regional administrative agencies in Finland operate under the national authorities, such as the Competition and Consumer Authority. However, Chapter 7 of the CPA requires that all of the supervisory authorities operate in appropriate co-operation with one another. ${ }^{*} 45$ Still, it is worth noting that neither of the authorities has promulgated mutually agreed upon guidelines regarding the division of supervision between the authorities, which would serve to clarify the situation from both the consumer creditors' and consumers' perspective.

Consumer lending can also be considered an information process, because of the large volume of financial and identity-verification information gathered from the consumer in the creditworthiness assessment. From this perspective, the consumer creditor must comply with personal-data and credit-data regulations, which are supervised by the Data Ombudsman. ${ }^{*}{ }^{146}$ However, the CPA requires the consumer creditor to assess the consumer's creditworthiness from the consumer-protection perspective, with the result that the consumer authorities and the Regional State Administrative Agency of Southern Finland also supervise the lending process in determination of whether the creditor is in compliance with the consumer-protection regulation.

The focus of supervision as conducted by the authorities is on the consumer creditor's consumer lending business as a whole. In essence, the authorities are not entitled to intervene in separate consumer relations or agreements, nor are they allowed to resolve disputes between creditors and consumers. ${ }^{*} 147$ Any such disputes shall be filed in the court system or through alternative dispute-resolution organs, such as the Consumer Disputes Board. This notwithstanding, the Data Ombudsman is entitled to issue decisions and legal orders to the consumer creditor in individual cases with regard to the customer's right to inspect the data concerning him or her, or rectification of false information. ${ }^{*} 48$

Authorities, however, receive customer feedback that is utilised for various supervisory means as well as in guidance for consumer creditors. The main role of the feedback is, therefore, to inform the authority of a grievance in consumer lending rather than to settle disputes. The authorities also follow the praxis of courts and alternative dispute-resolution organs in order to stay up to date on current, relevant problems.

\subsection{Sanctions}

Each consumer lending supervisory authority is entitled to impose sanctions independently. As was stated in the previous section, the supervisory authorities are not entitled to intervene in separate consumer relationships or agreements, and sanctions shall be imposed only on the basis of the consumer creditor's practices as a whole.

The Regional State Administrative Agency of Southern Finland shall prohibit operation of a consumer-credit business if the consumer lending activities are conducted without an appropriate registration or licence required by the law. ${ }^{*} 49$ A prohibition can also be issued, for special reasons, with respect to a person who works for or on behalf of the creditor-for example, as an agent. In addition, a person who

144 RA, Section 9.

145 CPA, Chapter 7, Section 51.

146 CIA, Section 33; Personal Data Act, Section 38.

147 This is expressly stated in the legislative history for the law pertaining to the Finnish FSA (see A. Makkonen (see Note 48), p. 213).

148 Personal Data Act, Section 40.

149 RA, Section 11. 
operates a consumer lending business without registration or a licence as required by law can be deemed to have committed a creditor offence entailing a fine or imprisonment for up to six months. ${ }^{*}{ }^{150}$

The Regional State Administrative Agency of Southern Finland may also put in place a partial or complete temporary prohibition of consumer lending activity in circumstances wherein the creditor has seriously ignored the obligations required under the law, or where the creditor continues unlawful practices despite prior notices and warnings. ${ }^{* 151}$ In this respect, all types of obligations set forth by law-not only requirements based on the CPA's Chapter 7 but also other regulations, such as other provisions in the CPA's chapters 2 and 3 and in relation to a creditor's obligation to submit necessary information to the relevant supervisory authorities-are taken into consideration. The agency is entitled to impose a conditional fine on the creditor, if necessary, as a punitive action. ${ }^{* 152}$

The most severe sanction the Regional State Administrative Agency of Southern Finland is able to impose is removal of a consumer creditor from the creditor register. Removal from the register would be as a result of the creditor or its senior management seriously and consistently neglecting obligations of operation and conduct as required by law, and, in addition, the creditor would have been previously made subject to a lending prohibition. Moreover, a creditor may be removed from the register if found to be merely a front organisation, conducting the consumer lending business on another's behalf. Also, when a creditor no longer meets the requirements for law-based registration, such as reliability and the necessary knowledge of consumer lending, that creditor shall be stricken from the register. ${ }^{*} 153$

The Consumer Ombudsman (CO) and the Market Court are also entitled to impose sanctions. The CO is entitled to prohibit a practice temporarily if that prohibition is not significant from the perspective of legal praxis or otherwise and may also issue a prohibition for special reasons in urgent cases. ${ }^{*} 54$ In other cases, any prohibition is imposed by the Market Court. ${ }^{*} 155$ The prohibition can be supplemented by a conditional fine in either of these instances. ${ }^{*} 56$

The sanction power of the $\mathrm{CO}$ and the Market Court is based not on consumer-credit provisions in the CPA's Chapter 7 but on the general provisions on consumer marketing and consumer relations found in the CPA's chapters 2 and 3. However, the scope of these general provisions is very wide, which results in the de facto large-scale sanctioning powers of the $\mathrm{CO}$ and the Market Court. Consequently, the sanction powers are much wider than the consumer-credit provisions of Chapter 7 of the CPA on their own indicate.

\section{How consumer-credit regulations affect contractual obligations}

A relevant question is whether consumer-credit regulations (such as provisions in the CPA's Chapter 7 and the Registration Act) affect separate credit agreements. In other words, if the creditor does not comply with, inter alia, good lending practice, the creditworthiness assessment obligation, the identity verification obligation, credit price regulations, or the limitations on night-time lending or conducts consumer lending business without consumer-credit registration, how do these unlawful practices affect the consumer's contractual obligations? Can the loan amount, interest rate, or credit costs be nullified or reduced in these cases? This section explores some associated perspectives, without attempting to provide a complete overview.

As was stated in the previous chapter, the supervision authorities are entitled to impose sanctions when a creditor neglects these obligations fundamentally or repeatedly but not on the basis of only a single case. Furthermore, while supervisory authorities are entitled to sanction only the creditor, these sanctions do not affect credit agreements.

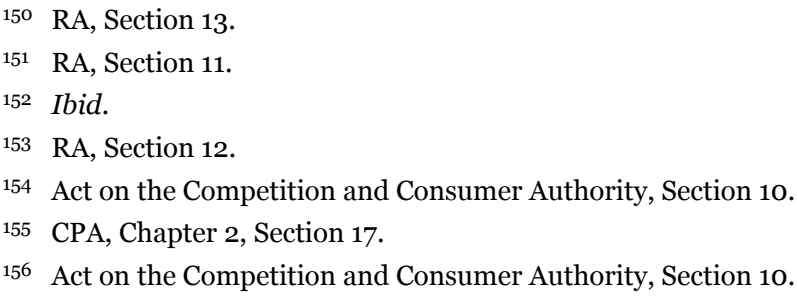


Some of the consumer-credit provisions are very efficient in their direct effects on credit agreements. According to the $\mathrm{CPA},{ }^{*} 157$ a consumer-credit agreement must be made in writing or electronically-if not, the consumer is obliged to pay back only the capital amount of the loan. In addition, the consumer is obliged to pay only those credit costs that have been agreed on in a written or electronic agreement. ${ }^{*}{ }^{8} 8$ Also, the provisions pertaining to maximum credit costs (a 'rate cap'), interest for late payment, and debt-collection costs have a direct effect on credit agreements. They determine the maximum costs that the creditor or the debt-collection agency is allowed to collect from a consumer. ${ }^{*} 159$ Since the creditor is obliged to specify the basis of the claim-such as the capital amount, costs, and interest-in the application for summons, these cost restrictions are generally applied by the courts ex officio if this is possible. ${ }^{* 160}$

There are no precise regulations on the contractual consequences of neglecting the provisions on responsible lending-such as those for good lending practice, creditworthiness assessment, and identity verification. The consumer-credit regulation expressly states neither the contractual consequences of granting loans to non-creditworthy consumers nor those for neglecting the ban on night-time lending. It is somewhat unclear whether these legal rules are only supervisory means for authorities or they also have some effect on contractual obligations. Regardless, these circumstances do not usually arise in court proceedings related to debt collection, since the creditor is not obliged to provide information on these issues in the summons application. Consequently, the court cannot apply the above-mentioned legal rules ex officio.

The most obvious consequences are basically credit losses for the creditor. If the debtor fulfils the requirements for a private person's debt adjustment, ${ }^{*} 161$ all of the debts will be settled via the debt-adjustment procedure. Reform of provisions for private persons' debt adjustment is currently pending. The working group suggests that a creditor's actions-such as having complied or not with good lending practice and the creditworthiness assessment obligation-must also be taken into consideration in determination of the requirements for the consumer in the debt-adjustment process. ${ }^{*} 162$ Consequently, neglecting the obligations related to responsible lending may lead to reduction of credit amounts and credit costs via the debt-adjustment process in future.

The consequences may arise in application of the general principles of contract law, such as the unreasonability doctrine that is included in the Contracts Act ${ }^{*} 63$ (CA): "If a contract term is unfair or its application would lead to an unfair result, the term may be adjusted or set aside. In determining what is unfair, regard shall be had to the entire contents of the contract, the positions of the parties, the circumstances prevailing at and after the conclusion of the contract, and to other factors. ${ }^{, * 164}$ Thus far, there is no case law applying unreasonability doctrine to instant loan agreements. ${ }^{* 165}$ It is more likely that a case can be made for revisiting the guarantee given by a private individual on the basis of special rules in the law pertaining to guarantees. ${ }^{* 66}$ However, the debtor receives the funds and therefore a benefit, unlike the guarantor, who receives no benefit. For this reason, mediation for credit agreements differs markedly in nature from mediation related to guarantees. This suggests that unreasonable credit agreements will generally be mediated only with regard to the cost of credit. In addition, the Interest Act includes a certain adjustment

157 CPA, Chapter 7, Section 17: 'A consumer-credit agreement shall be made in writing and the consumer shall be provided with a copy of the agreement. The agreement may also be made electronically in a way that allows the unchanged reproduction and storage of the information by the consumer.'

${ }_{15} \mathrm{CPA}$, Chapter 7, Section 17. See also A. Makkonen (see Note 48), p. 215.

159 CPA, Chapter 7, Section 17a; DCA, Sections 10 a, $10 \mathrm{c}$, and $10 \mathrm{~d}$.

160 A court procedure is an obligatory phase before the legal-enforcement process. See Subsection 4.2 ('The information provided by credit-data registers') and Note 88. In practical terms, it is impossible in many cases to determine whether the creditor has complied with the 'rate cap' provision, because the 'rate cap' is not based on exact maximum amounts (as the maximum debt-collection costs are); instead, it is based on complex calculation of the actual percentage rate, and the creditor is not required to submit the credit agreement in its entirety to the court in summary procedures.

161 See Subsection 5.3, on adjustment of private debts.

162 See Subsection 5.3 of this article.

163 Laki varallisuusoikeudellisista oikeustoimista (Contracts Act), 228/1929, as amended.

164 CA, Section 36.

165 However, in 1996 the Supreme Court held that total credit costs consisting even 50\% of the capital amount (original capital amount was 218,000 mk and credit costs around 124,000 mk) were not unreasonable in short-term bank financing since these costs did not differ from the general short-term financing price range in the banking sector in the beginning of $1990 \mathrm{~s}$ and the price level of short-term financing was generally known. In addition, most of these credit costs were caused by extending the original repayment period. See case KKO (referring to the Supreme Court) 1996:90.

166 Laki takauksesta ja vierasvelkapanttauksesta (Act on Guarantees and Third-Party Pledges), 361/1999, as amended. 
provision for late-payment interest on private debts. ${ }^{*} 167$ This provision applies mainly to long-lasting overindebtedness and when the amount of the interest for late payment has increased to beyond the level that the debtor is able to overcome. ${ }^{*} 68$

By a recent decision of the Turku Court of Appeals, ${ }^{*} 169$ a consumer-credit agreement was declared invalid because the creditor did not hold appropriate registration as a provider of consumer credit. The creditor was an Estonian loan company that had conducted instant-loan business in Finland for several years. ${ }^{{ }^{*} 70}$ The decision of the district court indicates that the Estonian company had transferred the credit agreements to a Finnish debt-collection company immediately after granting the loans. In addition, the debt-collection agency did not hold a licence to conduct debt-collection business. ${ }^{*}{ }^{171}$

Since the creditor and the debt-collection agency did not fulfil the registration or licensing obligation, the activities of the companies were seen as unlawful and contra bonos mores by the court. Furthermore, the loan agreement itself was seen as unlawful and non-binding. The main principle of Finnish contract law is that where a contract is invalid, the parties must return the consideration. ${ }^{{ }^{1} 172}$ Still, the district court and the court of appeals applied the principle of non-interference (puuttumattomuusperiaate) ${ }^{*} 173$, which means that in cases of unlawful and contra bonos mores acts a party is not obliged to fulfil its obligations or provide reimbursement: the consumer debtor was not obliged to pay back the loan amount, interest, or other costs. However, the court justified its decision only on the basis of the lack of registration as a consumer-credit provider and debt-collection licence-no other unlawful actions or delinquencies were pointed out, such as neglect of good lending practice, the identity verification obligation, or creditworthiness assessment obligation. ${ }^{*}{ }^{*} 74$ At the time of writing, this judgement is not yet final.

\section{New regulations-new problems?}

It can be stated that instant-loan regulation has been amended 'step by step'-first by softer means, such as identity verification, supervision, disclosure obligations, and the focus on good lending practice. The first amendments have been criticised as only 'technical adjustment' of the legal norms. ${ }^{*}{ }^{175}$ Although many important enhancements to consumer protection-especially the identity verification obligation-were made, in fact, no research or statistics give any indication that these regulations in themselves have been effective against the indebtedness problems accompanying instant loans.

Some of the new regulations were a result of very active political discussion ${ }^{* 176}$, alongside the implementation of the Consumer Credit Directive. Even the majority of the members of the Finnish Parliamentregardless of their political affiliation-agreed in 2011 that the indebtedness problems caused by instant

167 IA, Section 11.

168 Case KKO (referring to the Supreme Court) 2006:66.

169 Turku Court of Appeals (Turun hovioikeus) case 209, of 12.2.2014. The decision was not yet final at the time of writing; it may be appealed.

170 The company claimed that it conducted consumer-loan business in Finland only temporarily, for which reason it was not obliged to be registered as a consumer-credit provider (see Section 2, 'Registration of consumer-credit providers'). The Court found that the practice was ongoing and not, as claimed by the company, temporary.

171 Debt-collection business is subject to a licence in Finland. See Laki perintätoiminnan luvanvaraisuudesta (the Act on Licensing of Debt Collection Businesses), 517/1999, Section 2. A debt-collection agency that is part of the same corporate group as the creditor, however, is not required to be licensed. In the case mentioned, the collection agency claimed to be part of the same corporate group as the creditor but was not able to provide any proof of that claim.

172 M. Hemmo. Sopimusoikeus I ['Contract Law I']. Jyväskylä, Finland 2003, pp. 320-322 (in Finnish).

173 The principle of non-interference has previously been seen as related to, inter alia, false transactions (see M. Hemmo (ibid.), pp. 429-431), illegal gambling (ibid., pp. 436-437), and prostitution (KKO case 2005:72).

174 The Consumer Agency published a bulletin on 14.9.2012 wherein the agency warned customers about the inappropriate and misleading practices of the same consumer creditor and debt-collection agency and advises consumers to consider appealing to the reasons for which the amount of, or basis for, the debt is unclear. See the bulletin entitled 'Neljän pikaluottoyhtiön perinnässä epäselvyyksiä’ ['Obscurities observed in debt collection of four instant-loan companies'], available at http://www. kuluttajavirasto.fi/fi-FI/Uutiset/2012/tiedote/tiedotteet-2012/neljan-pikaluottoyhtion-perinnassa-epaselvyyksia (most recently accessed on 6.4.2014) (in Finnish). This argument did not arise in the case considered here.

175 P. Länsineva. Pikaluottojen sääntely ja perusoikeudet ['Instant-loan regulation and the fundamental rights']. - Lakimies 2010/6, p. 1055 (in Finnish).

176 N. Jakobsson. Pikaluotot - Hämärää markkinointia, kohtuuttomia sopimusehtoja ja koronkiskontaa? ['Instant loans-unclear marketing, unreasonable terms and usury?'] - Helsinki Law Review 2008, pp. 147-148 (in Finnish). 
loans are so severe for consumers that either instant loans should be totally banned or the consumer-credit legislation must be otherwise reformed. ${ }^{*}{ }^{177}$ This led to legal limits on the costs of consumer credit under EUR 2,000.

The new laws may solve some of the 'traditional' problems related to instant loans-in particular, high credit costs, unclear marketing, excessively easy access to loans, and granting of credit in the absence of ability to pay. The statistical information indicates that the legislative changes in 2013-in particular, the limitation on credit costs-may have caused some decrease in the size and number of loans granted and in credit costs, but at the same time the average payment period has significantly increased. One third of consumer-loan companies closed down their consumer lending business in 2013. The number of payment defaults (court decisions on outstanding loans) continued to increase in 2013, but this may be explained by payment defaults being usually established in the credit-data registers several months after the due date of the loan.

\section{Key figures for instant loans in 2008-2013:}

\begin{tabular}{|l|c|c|c|c|c|c|}
\hline & $\mathbf{2 0 0 8}$ & $\mathbf{2 0 0 9}$ & $\mathbf{2 0 1 0}^{*}$ & $\mathbf{2 0 1 1}$ & $\mathbf{2 0 1 2}$ & $\mathbf{2 0 1 3}$ \\
\hline $\begin{array}{l}\text { New instant loans } \\
\text { (thousands of euros) }\end{array}$ & 187,711 & 226,259 & 244,051 & 322,188 & 394,357 & 322,912 \\
\hline $\begin{array}{l}\text { Number of new instant loans } \\
\text { granted }\end{array}$ & $1,027,706$ & $1,130,783$ & $1,183,335$ & $1,410,304$ & $1,552,586$ & $1,013,878$ \\
\hline $\begin{array}{l}\text { Outstanding instant loans }{ }^{*}{ }^{* 179} \\
\text { (thousands of euros) }\end{array}$ & 28,062 & 45,227 & 56,167 & 98,447 & 134,067 & 116,065 \\
\hline Average amount (euros) & 182 & 200 & 206 & 228 & 254 & 318 \\
\hline $\begin{array}{l}\text { Average payment period for } \\
\text { new loans (Q4 only) (days) }\end{array}$ & 28 & 29 & 32 & 33 & 38 & 96 \\
\hline $\begin{array}{l}\text { Costs for new loans } \\
\text { (percentage) }\end{array}$ & $23.7 \%$ & $26.7 \%$ & $26.1 \%$ & $24.5 \%$ & $23.0 \%$ & $19.1 \%$ \\
\hline $\begin{array}{l}\text { Total number of payment } \\
\text { defaults }{ }^{* 180} \text { for private persons }\end{array}$ & N/A & 228,430 & 237,447 & 280,767 & 334,795 & 343,530 \\
\hline $\begin{array}{l}\text { Total number of instant-loan } \\
\text { payment defaults }{ }^{*} 181 \text { and their } \\
\text { percentage of all payment } \\
\text { default }\end{array}$ & N/A & $\begin{array}{c}54,762 \\
23 \%\end{array}$ & $\begin{array}{c}49,117 \\
21 \%\end{array}$ & $\begin{array}{c}81,735 \\
29 \%\end{array}$ & $\begin{array}{c}109,852 \\
33 \%\end{array}$ & $\begin{array}{c}115,718 \\
34 \%\end{array}$ \\
\hline $\begin{array}{l}\text { Number of registered } \\
\text { consumer-loan companies }{ }^{* 182}\end{array}$ & - & - & - & 86 & 87 & 55 \\
\hline
\end{tabular}

* Laws entering into force in February 2010, on the obligation to verify a consumer's identity (see Subsection 3.4), limitations on night-time credit accessibility (see Subsection 6.5), and amendment of usury laws (see Subsection 6.4), and December 2010, on registration of consumer-credit providers, good lending practice, the obligation to assess the consumer's creditworthiness, and reform of the supervision system (see Sections 2, 3.1-3.3, 5.1, and 7).

** Laws entering into force in March 2013, on reform of debt-collection costs' regulation (see Subsection 6.3), and June 2013, on credit prices' regulation (see Subsections 3.2 and 6.1) and renewal of the creditworthiness assessment obligation (see Subsection 3.3).

177 Parliament members' initiatives LA 58/2011 vp (signed by 116 out of 200 MPs) and LA 59/2011 vp (signed by 127 out of 200 MPs). In addition, the Social Democrats introduced a motion in 2007 for the supervision of instant-loan companies to be handled by the Finnish FSA (LA 103/2007 vp).

178 Official Statistics of Finland (OSF): Outstanding credit [e-publication]. ISSN=2342-2661. Helsinki: Statistics Finland. Available via http://www.stat.fi/til/lkan/tup_en.html (most recently accessed on 22.3.2014).

179 Ibid.

180 Credit-data register of Suomen Asiakastieto Oy, with the registered court decisions related to all consumer debts (including also other debts than credit agreements, such as unpaid bills). I would like to thank Suomen Asiakastieto Oy for supplying statistical information for this article.

181 Credit-data register of Suomen Asiakastieto Oy. Instant-loan payment default is defined as a court decision pertaining to lump-sum consumer credit (based only on a credit agreement) of under EUR 300.

182 Source: Administrative Agency of Southern Finland, January 2014. The Registration Act, which entered into force in 1.12.2010, specifies that a consumer-credit provider is obliged to apply for registration-unless it holds a credit-institution licence. See Section 2, on registration of consumer-credit providers. 
However, this statistical information should be subjected to a critical eye. From examination of the consumer-credit-provider register, 44 Internet-based consumer-loan services were found and analysed in April 2014. In consequence, three totally new types of instant-loan product were discovered.

Firstly, 23 of the companies provide consumer loans amounting to, at minimum, EUR 2,000. As the credit price regulations pertain to consumer loans of less than EUR 2,000, ${ }^{* 183}$ the creditors are clearly tending to raise the minimum amount of the loans. Of these loan services, 16 provided only credit limits, and in eight of these cases, the terms and conditions of the credit included significant restrictions on the use of credit limits, which means in effect that the credit limit is only formal and the consumer is able to use only a part of it.

Secondly, 13 consumer-credit services required a guarantee as security for the loan. Both personal guarantees and credit guarantees (granted by an affiliate of the creditor) were usually accepted, but in practice, the credit guarantee is the only option for instant granting of the credit. The commission fees for the credit guarantee varied from 22 to 33 per cent of the loan amount, which is calculated neither in the actual percentage rate nor in the scope if the credit price regulations. An alarming observation was that none of the credit services disclosed this information clearly on their Web sites. Only in five of these cases was the commission fee for the credit guarantee revealed in the terms and conditions of the credit on the publicly facing Web site. In the other eight cases, these costs were impossible to find without registration for the consumer-loan service. ${ }^{*} 184$

Thirdly, three of the consumer-credit services required the loan amount to be transferred to a pre-paid payment card without the possibility of withdrawing the money. This way, the consumer credit can be considered a goods-or-services-related credit and beyond the scope of credit price regulation.

Moreover, although there are obligations of identity verification, creditworthiness assessment, and the credit agreement being made in written or electronic form, SMS lending is not totally deceased. In 18 consumer-credit services, after the creditworthiness assessment and identity verification are conducted via customer registration, application for new loans and use of the credit limit is possible via SMS messages through a personal PIN code or similar verification.

According to a report of the Finnish Tax Administration (from April 2013) ${ }^{*} 185$ that considered instantloan businesses between 2007 and 2011, some 35\% of the registered consumer creditors or the persons in charge thereof were indicated as lacking financial reliability. In this report, financial reliability was determined on the basis of previous bankruptcies, negative equity, unprofitable accounting periods, debt-recovery proceedings, and significant (i.e., over EUR 5,000) outstanding tax debt. Almost a third of the instantloan companies were indicated to have outstanding tax debt, which proportion is double the average across all Finnish businesses. However, consumer creditors' financial reliability is not expressly mentioned in the provisions pertaining to the requirements related to the registration of consumer-loan providers.

\section{Conclusions}

The Finnish legislator has developed national legislation as a solution to the problems related to instant loans. Flexible provisions, such as good lending practice and creditworthiness assessment, were intended to prevent all types of inappropriate practices in consumer lending. Still, only specific restrictions have had a notable influence in responding to the problems faced in the country in recent years: according to the statistics, credit costs and the number of new loans have decreased. Unfortunately, it seems that the purpose of the legislator has become somewhat watered down. There have been remarkable side effects, such as tripling of the average payment period, higher loan amounts, and more complex loan products-some of them with the same level of costs as before the legislative changes. In fact, the definition of an instant loan is no longer as exact as it used to be: it is not only a small-amount lump-sum loan with a short payment period, but it also can be a sort of credit limit amounting to thousands of euros or a consumer loan with a

183 See Subsection 6.1, 'Regulation of credit prices'.

184 At the moment, there is a case pending with the Market Court that has to do with the commission fees linked to an instant loan's credit guarantee.

185 The report entitled 'Selvitys pikalainayrityksistä' ['Report on instant-loan companies'] by the Finnish Tax Administration (Verohallinto), 10.4.2013, available at http://www.vero.fi/fi-FI/Tietoa_Verohallinnosta/Tiedotteet/Tietoa_harmaasta_taloudesta_Selvitys_pik(26905) (most recently accessed on 6.4.2014) (in Finnish). 
credit guarantee. All in all, this development introduces many new challenges not only for consumers but also in collecting of statistical information.

There are two essential perspectives related to credit price regulation that should be taken into more thorough consideration. Firstly, it seems that a maximum actual percentage rate for consumer loans' total costs is too easily avoidable, by means such as lengthening the payment period or inventing new loan products. Instead, enacting a maximum nominal amount for consumer-loan costs, including costs of creditrelated ancillary services, would be worthy of consideration. Secondly, the scope of the credit price regulation should be expanded to include all types of credit and also goods-or-services-related credit products, because of the rapid development of new payment methods.

On the other hand, it has also been suggested that a compulsory waiting period ('cooling-off period') be instituted between granting and dispensing of the credit to the customer, as an alternative to price regulation. This solution has been seen as a way to help people avoid becoming indebted imprudently. ${ }^{*} 186$

Another notable issue seems to be the supervisory system in place for consumer creditors. As was stated in Section 7, several authorities are involved in consumer creditors' supervision. The legislation does not define which one of these supervisory authorities takes overall responsibility for the supervision or even a division of authorities' supervisory duties. The CPA only requires that the supervisory authorities co-operate with each other as is appropriate. ${ }^{* 187}$ It should be taken into consideration whether the tasks of individual supervisory authorities should be specifically defined in the law. Alternatively, one solution may be for the authorities to resolve the question independently, by, for instance, announcing guidelines for the division of supervisory duties among the authorities.

Consolidating the supervision of consumer lending regulation with a single authority might also be worth considering, for several reasons. Such a solution would, in particular, clarify the supervision, which would be a benefit for consumers and creditors alike. Furthermore, it would prevent the diverging interpretations of law that might be possible in dealing with various authorities. Consolidated supervision might also be justified on the basis of efficiency, as public-sector effectiveness is currently a very topical issue in Finland.

The present legislation does not provide extensive requirements for financial reliability for consumerloan providers, regardless of the fact that consumer-loan business is economically significant activity. The reliability of the consumer creditor is evaluated basically in terms of crime history. The Finnish Tax Administration has suggested reforming the requirements related to consumer lending business in such a way that especially the financial reliability and financial background of the creditor and its persons in charge could be taken into consideration more particularly. ${ }^{*} 188$

Finnish law includes two essential rules related to responsible lending-on good lending practice and the obligation of creditworthiness assessment-which should be utilised more, for instance, through selfregulation or public guidelines set forth by the authorities. Qualified examples of this include good banking practice, formulated via the banking sector's self-regulation, and the guidelines on good debt-collection practice, which resulted from co-operation among consumer-protection authorities, debt-collection agencies, and consumer associations. However, a practical challenge is that consumer creditors are not fully organised, for example, with a union of their own, with the result that such self-regulation cannot yet be expected.

If providing instant loans were to be restricted by legislative means, what would replace them? About 30 municipalities in Finland provide social lending services for their residents who, because of their low income and scant financial means, are unable to obtain credit on reasonable terms elsewhere. ${ }^{*} 89$ Social lending is based on special legislation that includes provisions pertaining to granting of credit, terms and conditions for social credit agreements, and financial counselling. ${ }^{*} 190$ The maximum interest rate for social credit is the reference rate under the Interest Act's Section $12^{{ }^{*} 191}$. An essential element of the social credit

186 O. Juurikkala (see Note 10), pp. 30-31; O. Juurikkala. Pikavippien sääntely: Ei korkokattoa, vaan erityinen harkinta-aika ['Instant-loan regulation: Not a rate cap but a special waiting period']. - Oikeus 2012/3, pp. 458-459 (in Finnish).

187 CPA, Chapter 7, Section 51.

188 See the report of the Finnish Tax Administration (see Note 185).

189 For instance, see the position paper of Mun talous (the My Economy Network). Helsinki 3.2.2014 (in Finnish). Available at http://www.takuu-saatio.fi/@Bin/494977/Kannanotto+sosiaalinen+luototus.pdf (most recently accessed on 12.4.2014) (in Finnish).

190 Laki sosiaalisesta luototuksesta (Act on Social Lending), 20.12.2002/1133, as amended.

191 See Subsection 6.1, 'Regulation of credit prices'. 
is fee-free financial counselling, which must be provided for the consumer if needed. ${ }^{*}{ }^{*}$ Municipalities are entitled to determine the credit-granting policy independently. ${ }^{*}{ }^{193}$ Although the Act on Social Lending came into force in 2003, social credit is still a very rare financing 'product': the latest survey, from 2010, indicates that there were only 780 cases of social credit being granted in 2010. ${ }^{{ }^{1} 94}$ The majority of municipalities do not provide social lending services. ${ }^{*} 195$ It has been widely stated that social lending services should be expanded nationwide, however, since smaller consumer loans with low costs and financial advising services are not a sensible combination for businesses. ${ }^{*} 196$

192 Act on Social Lending, Section 9.

193 Act on Social Lending, Section 2. For example, the City of Oulu grants social credit only for purposes of undertaking studies.

194 National Institute for Health and Welfare (Terveyden ja hyvinvoinnin laitos). Sosiaalinen luototus 2010 - kuntakyselyn osaraportti ['Social lending in 2010 - a survey report']. Available at http://www.thl.fi/tilastoliite/tilastotiedotteet/2011/Tr40_11. pdf (most recently accessed on 12.4.2014) (in Finnish).

195 According to the Act on Social Lending (Section 2), municipalities are not obliged to provide social lending services.

196 For instance, see O. Juurikkala (see Note 186), p. 459. 